\section{Zdzisław Pawłowski}

Uniwersytet Mikołaja Kopernika w Toruniu zpawlowski_55@o2.pl

ORCID: 0000-0002-3042-351X

DOI: http://dx.doi.org/10.12775/BPTh.2019.005
Biblica

et

Patristica

Thoruniensia

12 (2019) 1: 71-89

ISSN (print) 1689-5150

ISSN (online) 2450-7059

\title{
To Eat or Not to Eat. Politics, Religion, and Eating in 1 Kings $13^{*}$
}

\section{Jeść czy nie jeść. Polityka, religia i jedzenie w 1 Krl 13}

\begin{abstract}
According to the cultural anthropology eating together, especially during feasts is not only of social significance, strengthening community bonds but also bears some political and religious consequences. The motif of eating which gives a thematic orientation to the whole narrative in 1 Kings 13 has been skilfully interwoven into the narrative structure of the confrontation between the king and the prophet, representing respectively politics and religion. The story consists of two episodes. The first one (13:1-10) describes the relationship between politics and religion in an encounter of the man of God from Judah with the king. The second one (13:11-34) gives a full account of a conflict within religion regarding a relation to politics. Both the man of God and the old prophet fail to live up to the message of God. However, their failures do not undermine the word of God proclaimed by them because its strength and persistence is based on the faithfulness of God which accompanies the sinful people.
\end{abstract}

Streszczenie. Według antropologii kulturowej wspólne jedzenie, zwłaszcza podczas świątecznych posiłków, ma nie tylko znaczenie społeczne, wzmacniające więzi wspólnotowe, ale niesie także określone skutki polityczne i religijne. Motyw posiłku, nadający tematyczną orientację opowiadaniu w $1 \mathrm{Krl}$ 13, został umiejętnie wpleciony w narracyjnie skonstruowaną konfrontację między królem i prorokiem, reprezentującymi odpowiednio politykę i religię. Składająca się z dwóch epizodów opowieść, opisuje najpierw relację religii i polityki, w pełnym napięcia spotkaniu między człowiekiem Bożym z Judy i królem (1 Krl 13,1-10), a następnie podejmuje problem konfliktu wewnątrz religii o stosunek do polityki (1 Krl 13,11-34). Obydwaj jej przedstawiciele, człowiek Boży i stary prorok nie dorastają do treści wypowiadanego w imię Boga orędzia. Tym niemniej, ich słabości nie podważają głoszonego przez nich słowa, którego mocą jest wierność Boga, towarzysząca grzesznemu ludowi.

The article is, to a large extent, a modified and extended version of a popular science study Król i dwaj prorocy (The King and Two Prophets) which was published in: Pastores 78/1 (2018), pp. 7-16. 
Keywords: eating; word of the LORD; man of God; king; prophet; politics; religion; cultural anthropology; hermeneutics of history.

Słowa kluczowe: jedzenie; słowo PANA; człowiek Boży; król; prorok; polityka; religia; antropologia kulturowa; hermeneutyka historii.

an eating together or its refusal have religious and political consequen-
ces? The close relationship of religion, politics and food seems to confirm the words of Amaziah, the priest of the national shrine of Israel, addressed to the prophet Amos: "Get out, you seer! Go back to the land of Judah. Earn your bread there and do your prophesying there. Don't prophesy anymore at Bethel, because this is the king's sanctuary and the temple of the kingdom." (Am 7:12-13). A combination of politics and religion seems to be something natural and understandable here. What appears quite unusual is their reference to eating. Cultural anthropology, however, gives grounds to see them together. According to C. A. Hastorf, eating appears as an important occasion for social interaction, giving a sense of pleasure and certainty, however, it is not devoid of any worries and fears. It is located at the very center of an ideological structure in which economic aspects are inseparable from political action or individual habits. It emphasizes that through daily activities related to eating, people not only sustain their lives, but also create themselves mentally, psychologically and physically. Thus, a meal can be both a physiological activity and a political and social action which may strengthen and transform relationships between participants. People sitting at the table function in many different communities, however, when eating together, they enter into special relationships of trust and self-support, creating a kind of imaginary kinship which also operates outside the meal. Thus, the social world is never far from the food which people share with each other. For this reason, it may be disposed of variously through the method of preparing meals, their grandeur, type and succession of dishes in order to achieve certain political and religious effects. ${ }^{1}$

According to some anthropologists, eating, especially during feasts, becomes the basic tool of influence in the sphere of politics. Celebrations are the rituals of social events in which feasting becomes a political and symbolic drama with far-reaching consequences. Combining hospitality with eating together transforms it into a specialized form of exchange of gifts, creating a network

1 C.A. Hastorf, The Social Archeology of Food. Thinking about Eating from Prehistory to the Present, p. 1,7n. Cf. Gen 18:1-15. 
of mutual obligations between the host and guest, the similar one which exists between the donor and the recipient. Although the food disappears during a feast, mutual obligations remain, determining the direction and shape of future relations between them. Meals can thus be the subject of manipulation for ideological reasons as well as for more personal purposes. Food and drink demonstrate a powerful symbolic potential because they are a basic and continuous human need. As an expression of hospitality included in enjoying a feast together, they reflect an extremely political activity, which is not always recognizable. $^{2}$

A good illustration of this is the sumptuous feast prepared by Adonijah and described in 1 Kings 1:25. As a pretender to the throne, he invited carefully selected guests, among them the commander of the army of Joab, priest Abiatar and all the representatives of Judah, who thanks to their position and influence were supposed to help him achieve his intended purpose (1 Kings 1:7.9). The main and clear reason for inviting them to this grand feast was to ensure the succession of the throne after David's death. Through its abundance and grandeur, Adonijah wanted to influence the invited guests so that they would feel obliged to give him their support, elevating him to his father's throne. The omission of his brother Solomon, the prophet Nathan, the priest Zadok and the military commanders (1 Kings 1:8.10) is very meaningful in this situation. Their exclusion from the feast indicates Adonijah's intention to remove them from the kingdom, whose future ruler he wants to be. The prophet Nathan is aware of this, warning Bathsheba, the mother of Solomon, that both of them are in danger of certain death (1 Kings 1:11-12).

Apart from hospitality calculated to gain power which is dangerous to potential competitors who are not invited to a feast, there is another kind of hospitality which serves to strengthen asymmetrical relations in the structures of domination. By inviting the guest for a meal the host wants to subordinate him, gain his favor and loyalty. It is about accepting a pattern of hospitality which strengthens inequality in power relations. Those who fulfill the role of a guest symbolically recognize their status of service towards the role of a host and lack of reciprocation forces them somehow to submit and subordinate themselves.

Manipulations of the aforementioned patterns of hospitality usually take place by emphasizing the number of dishes or the feast style. The size and lavishness of the meal gives the impression required to gain support in the pursuit of power. On the other hand, the method and, above all, the circumstances in which the invitation to a feast is given are calculated to strengthen dispropor-

2 Cf. M. Dietler, "Feasts and Commensal Politics in the Political Economy. Food, Power and Status in Prehistoric Europe”, pp. 87-90 (87-125). 
tions in power relations. The institutionalization of the host's authority depends on this binding aspect of the feast combining unequal partners in the patron/ client relationship, becoming a political and symbolic instrument to legitimize differences in status, in which the king as a host presents himself as a patron and the guest acts as a client. ${ }^{3}$

Although the feast in 1 Kings 13 is not described in detail, it is known that both the meal offered to a man from Judah by the king and by an old prophet was certainly extremely festive and at the same time carried political and religious repercussions, as it was associated with the dedication of a new altar in the national shrine in Bethel and the inauguration of a new worship.

\section{The Structure and Literary Genre of the Narrative: a Legend or a Parable?}

The boundaries and unity of the text in 1 Kings 13 are the subject of controversy and are constantly discussed. Their source is the narrative continuity of the history of the reign of Jeroboam in 1 Kings 12:26-14:20. The beginning of the story in particular may seem difficult to determine, as the scene in 1 Kings 12:26-33 outlines the background and without knowing it one cannot understand the meaning of the events described in 1 Kings 13. It is easier to determine the ending of the episode, because in 1 Kings 14:1 there is a change of scenery: the new characters appear and the circumstances change. Nevertheless, from the point of view of the main characters, the temporal and spatial system and the thematic orientation, the text is characterized by quite clearly marked boundaries and despite the change of location in 1 Kings 13:11 it retains the unity of action. Apart from three main characters, King Jeroboam, a representative of politics, a man of God from Judah and an old prophet from Bethel, who are representatives of religion, the motif which unites the whole story is food which appears 11 times in the text. This is the only episode in the Books of Kings with such a frequency of terminology concerning food and meals, which like a mantra is repeated all the time in a relatively short story.

In the Bible, eating meals always signifies more than simply satisfying hunger because it accompanies the political arrangements (Gen. 26:30), as well as religious ceremonies (Ex 24:11). Eating changes its function when it accompanies the events during which tensions arise between politics and religion. Their source is most often prophets (though not all), who in their speeches place religion and politics on the level of mutual confrontation. The prophet

3 Cf. ibid., p. 97. 
speaks in the name of God criticizing the actions of the king, accusing him of deviating from God's commandments, while the king seeks in the worship and the speeches of prophets supporting him confirmation for his policy (see 1 Kings 22). The greatest distance in their mutual relations occurs when they meet face to face. The story in 1 Kings 13 opens the whole series of this kind of encounters and it is, to some extent, a model account as it contains not only a reprimand of God's man addressed to the king (1 Kings 13:1-10), but also takes up the problem of distinguishing between true and false prophets (1 Kings 13:11-32). ${ }^{4}$ What links these two episodes is both the unity of the place (Bethel) and time (the feast in the eighth month, on the fifteenth day of the month ) as well as the figure of the main character and the presence of the formula by the word of the LORD (1 Kings 13:1.2.5.9.17.18.32) and the motif of road (1 Kings 13:9.10.12.17.24.25.26.28.33) and meal (1 Kings 13:8.9.15.16.17.18.19.22 .23.28). The final aspect, although crucial for the development of the plot, does not attract much interest from the exegetes, for whom a motif of obedience and disobedience to the word of God is more important. However, the invitation to a meal by the king and refusal on the part of the man of God, and then the renewal of this invitation by the Bethel prophet and his acceptance must play a vital role in the encounter of politics and religion. ${ }^{5}$

The correct interpretation of it also depends, to a large extent, on the arrangements concerning the literary genre. Earlier exegesis treated it as a prophetic legend, whereas more recent research recognizes it as a prophetic parable with the elements of political allegory. As a parable, it has a didactic character, carrying an instructive message. The man of God is not, like in legends, worshiped and admired, but exposed and, in a sense, discredited. ${ }^{6}$ The lack of names is also a feature corresponding more to the nature of the parable than to the historical event. Apart from two mentions of Jeroboam's name right at the beginning (1 Kings 13:1.4), characters are represented by means of their offices: a man of God, a king and a prophet. In contrast, specific geographical names

4 Both episodes are framed with a description of Jeroboam's religious innovations, including the establishment of not only two competing against the temple in Jerusalem, sanctuaries at Dan and Bethel with their new priests, but also a new liturgical calendar with a different date of the main feast (1 Kings 12:25-33 and 13:33-34). This context of the story makes the event described there a breach in Jeroboam's account of reign and, at the same time, an interpretation key of the entire history of kings confronted with the prophetic word.

5 The theme of food and its function in the Old Testament is explored by N. MacDonald, Not Bread Alone: The Uses of Food in the Old Testament.

6 Cf. D.W. Van Winkle, "1 Kings XIII: True and False Prophecy”, p. 32n.; R. Boer, "National Allegory in the Hebrew Bible", p. 106nn. 
appear: Judah (13:1.12.14.21), Bethel (13:1.4.10.11.32) and Samaria (13:32). Their presence allows us to interpret the whole story in a political-religious key describing the rivalry between Judah (the man of God) and Israel (the king and the old prophet). Narrative analysis of the main characters' behavior offers an insight into complex and intricate relationships between religion and politics and shows the extent of their impact on each other. Although in each of them there are some rules and procedures of conduct, their use depends, to a large extent, on the beliefs and internal decisions of people involved in them.

\section{The Man of God and the King (1 Kings 13:1-10): to Accept or Not to Accept the Invitation?}

The arrival of the man of God from Judah to Bethel is preceded by the scene in 1 Kings 12:26-33. It describes the changes introduced by King Jeroboam in the structure of the religion of Israel. It also reveals the motives which guided him. These are not religious motives, but dictated by the fear of losing power. However, this fear is ungrounded because people from Israel consider him to be their natural leader and after unsuccessful negotiations with Rehoboam they immediately choose him as their king. All the reasoning in 12:26-27 reveals his inner uncertainty, resulting from the distrust of the word of God, given to him by the prophet Ahijah, containing the message that he will become the king of Israel, while David's descendants will keep power over Judah (1 Kings 11:38-39). ${ }^{7}$ Perhaps, his stay at Pharaoh's court where he went, fleeing from King Solomon and where he remained until his death (1 Kings 11:40) could have had some influence on his decisions. In Egypt he probably had the opportunity to experience the view that "the state also embodies itself and eternal order," which is celebrated in worship. ${ }^{8}$

In his modified form of religion, Jeroboam sees, above all, a tool to realize his own political aims, from which the strengthening of his royal power and the creation of a state independent from Judah are the priorities. Jeroboam's comprehensive religious reform, including places of worship, rites, calendar and priesthood, does not introduce any new elements and it is more an attempt to reverse those reforms which took place in Jerusalem. If the temple of Solomon, with its centralization of cult and theology of the Name (see 1 Kings 8:15-20), based on the Law of Moses, could be seen as a significant novelty in relation to

7 Cf. J.T. Walsh, 1 Kings, p. 172.

8 Cf. J. Assmann, Pamięć kulturowa. Pismo, zapamiętywanie i polityczna tożsamość w cywilizacjach starożytnych, pp. 182-2004, especially p. 184n. 
tribal religion with many sanctuaries retaining rituals associated with agriculture (see Judg. 6: 11-32), the changes introduced by Jeroboam have the status of reform, the aim of which is to restore the earlier traditions of the priest Aaron with his worship of the golden calf, made under the pressure of the people (cf. 1 Kings 12:28 from Ex. 32:1-6). Removing the Levites who supported Moses in his reaction to Aaron's decisions (Ex. 32:25-29) from the priesthood and designating loyal priests from the lower social classes, Jeroboam gave a clear signal that he intended to subordinate the religion to political power and treat it as an effective tool in building the unity of his people. ${ }^{9}$ From now on, the individual spheres of life are subjected to the king, who controls them through his appointed officials and religious officers. He accepts the maxim: the king is law (Rex lex) as a rule of his reign thus reversing the principle from Dt. 17:18-20 the law is the king (Lex rex) whose enforcement was one of the most important tasks of the prophets, especially when the kings wanted to put themselves above the law. ${ }^{10}$

Establishing a new feast and building the altar, Jeroboam behaves like King Solomon during the consecration of the temple of Jerusalem (1 Kings 8). However, during the inaugural rites (1 Kings 12:32-33), a man of God suddenly appears ${ }^{11}$ and interrupts the celebrations at their climax when the king himself approaches the altar to make offerings on it (1 Kings 13:1-2). ${ }^{12}$ He arrives sent by the word of the LORD, which will be the driving force behind the confrontational character of the whole encounter. ${ }^{13}$ The formula by the word of the LORD establishes here the beginning of the biographical episode of the man of God and defines two aspects of his prophetic identity: a journey not only on God's command but also in the power of God's word which sustains him on the way and determines the content of his statements and behavior. The king does not expect that the sequence of the celebrations planned by him will be interrupted by the prophetic word which disturbs not only the lofty atmosphere, but also ruins the carefully devised plans (1 Kings 12:26-28). Moreover, another sur-

9 Cf. P.J. Leithart, 1 \& 2 Kings, p. 97.

10 Cf. S.K. Tonstad, God of Sense and Traditions of Non-Sense, p. 218.

11 It is marked with a specific grammatical composition which interrupts previous events expressed by the sequence of verbs.

12 God speaks directly to Solomon four times in his dreams but never addresses directly Jeroboam. He reveals himself only by the word of the LORD addressed to him by the prophets. cf. J.T. Walsh, 1 Kings, p. 204 n.

13 The phrase "by the word of the LORD", used seven times dominates in the whole chapter. The use of this formula first by the narrator, and then its repetition in the mouth of the prophet may prove that his words are reliable, Cf. J.C. Long, Jr., 1 \& Kings, p. 169. 
prise awaits him. Instead of addressing the king directly, the man of God directs his prophecy against the altar in the form of an invocation: "O altar, altar". In biblical stories, it is not usual that someone turns to a certain object with the word of the LORD. ${ }^{14}$

The rhetorical figure used here, more frequent in poetry than in a narrative, is an expanded apostrophe, in which the speaker turns away from the group of his current listeners, in this case the king and the assembled people, and turns directly to the material thing. ${ }^{15}$ This behavior of the man of God must have caused general consternation, because it meant ignoring the king and could be interpreted as a manifestation of disregard for the seriousness of his office. Turning the attention from the ruler the invocation concentrates on the words of the prophet, which he intends to convey in the name of God. However, the message containing a distant, temporal perspective of the birth of a descendant of the lineage of David, who desecrates the altar erected at Bethel does not produce any reaction from Jeroboam (1 Kings 13:2). The next word, however, announcing the disintegration of the altar, incites his fury, because it signifies undermining the cult and the religious system as a whole introduced by the king. ${ }^{16}$ Stretching out his hand, Jeroboam orders: "Seize him!" (1 Kings 13: 3). The remark of the narrator about the disintegration of the altar, which is the confirmation of the sign given by the word of the LORD (1 Kings 13:4-5), is needed to explain why the man of God turned to the altar and not to the king. The basic function of the apostrophe is to give the elements of the physical world the ability to answer and a certain dose of irony is concealed in it. The king does not react with a change of attitude to God's admonition, it is accepted, however, by a material object whose obedience to the word of the LORD, in a symbolic and ironic way calls him to conversion.

The temporary sequence of events happening on this festive day, also plays an important role because it reveals the hidden motives of characters' behavior. This applies mostly to the king, who first ignores the announcement of desecration of the altar, and then reacts with anger at the word of its disintegration. In

14 J.T. Walsh, 1 Kings, p. 177.

15 It is necessary to distinguish between the lyrical and the oratory apostrophe. In the Greek oratory tradition, especially in court trials, the speaker changed the style of his speech and turning away (the meaning of the apostrophe) from the judge, addressed it to someone from the audience, perhaps to an opponent. Despite the temporary suspension, the speaker's intention was to continue in order to get interest and convince those who sat in court, see J.M. Smith, Apostrophe or the Lyric Art of Turning Away, pp. 411-437, especially p. 412.

16 The destruction of the altar of Baal by Gideon in Judg. 6:25-31 has a similar connotation. 
this way, he shows who is the master of the situation. A hand which cannot be withdrawn signifies the loss of that power. And only then does Jeroboam realize that he does not have it. He is forced to ask the man from Judah to plead to the LORD and ask Him for the restoration of his power. This might be interpreted as a recognition of the power of God and also of the authority of the man of God. ${ }^{17}$ Thus he found evidence of the influence of the word of the LORD on the political sphere.

A withered hand is a symbol of the loss of the ability to rule. The king, begging for healing, wants to regain his power. When his wish is fulfilled, he invites the prophet for a meal to his palace as a sign of his gratitude. ${ }^{18} \mathrm{He}$ promises him a gift too. What is the purpose of this behavior? The narrator does not reveal the king's true intentions, because the real policy is based on hiding them. It uses rhetorical means which, on the one hand, conceal the real intentions, and, on the other hand, try to catch the person in the network of dependencies.

Inviting the man of God, the king uses the term which Abraham used for three visitors who stopped and dined with him (Gen 18:5). Therefore, he predicts that the man from Judah must be hungry and tired after his journey. An invitation to a meal in such circumstances seems to be an expression of empathy and serves as part of the hospitality ritual, which is why the refusal turns out to be a serious offence to the king. At the same time, it shows that the word of the LORD places the man from Judah in a difficult situation. The invitation is strengthened by the promise of a royal gift which appears as a corruption proposal and must have raised suspicions about the sincerity of the intentions of the king. The narrator commenting on Jeroboam's behavior in 1 Kings 13:3334 has no doubts about the fact that he tried to take advantage of the hunger of God's man and his poverty (he traveled on foot, not on a donkey) to drag him to his side and use his authority to make his religious and political intentions credible (v.7). ${ }^{19}$ Besides, the man of God himself sees the king's intentions as a desire to bribe him. This is the reason why he categorically refuses, referring to the word of the LORD, who forbade him to eat and drink in this place and to return the same way (vv. 8-9). The man of God has to resolve the problem whether prophesying against the altar in the temple he can participate in the

17 Cf. Ex 4:21, where God asks Moses to make signs in front of the pharaoh to force him to let the Israelites leave Egypt.

18 See J.T. Walsh, 1 Kings, p. 180.

19 In a similar scene 1 Sm 15:24-31 Saul asks Samuel to go with him to offer sacrifice to the LORD, but the prophet refuses. Then the king repeats his request: "please honor me before the elders of my people and before Israel." Samuel agrees and follows him, by which he recognizes him as a king, although for God Saul is already a rejected king. 
feast given by the king and whether it does not undermine his earlier prophecy. If someone appears at the ceremony and participates in the feast given on this occasion, he shares both the political views and the religious beliefs of the host who invited him. A meal during such events is never neutral, but involves inevitable changes in the public image.

The refusal to participate in the feast of the dedication of a new shrine expresses the need for complete independence of the prophet from political power. He must be solely dependent on God, otherwise he will not be able to speak the truth in His name. On the other hand, the prohibition to return the same road becomes a symbolic activity visible both to the inhabitants of Bethel and to everyone who lives in Israel, and denotes the absolute and irrevocable nature of God's judgment. ${ }^{20}$ His departure from Bethel is accompanied by a call to keep his opinion different and not change it: keep your convictions and stand by them, otherwise, he will ruin their mission. The announcement made against the altar is not an individual and external task in relation to his calling, but a word which defines his identity to a certain degree, and which should be binding for him in his personal views, inducing him to preserve his otherness also on his way back. Therefore, he should not take any breaks to rest and refresh himself, thus expressing his sense of domestication and security. ${ }^{21} \mathrm{He}$ should remain hungry and homeless because his food and homeland is the word of the LORD, which made him a stranger there.

\section{The Man of God and the Prophet from Bethel (1 Kings 13:11-23): to Obey Hunger or God}

Leaving Bethel according to God's command, the man from Judah is probably thinking that his mission is over. He does not expect it to continue and end tragically. In place of the king, an old prophet comes in, who has been living in Bethel for a long time. This time, however, the confrontation is not based on a relationship of religion and politics, but different religious attitudes towards politics which provoke a dispute within religion. He is not prepared for a meet-

20 Cf. 2 Kings 19:28.33, where the Assyrian army returned the same way, not having achieved the goal of capturing Jerusalem. On the other hand, in Dt. 17:16, a ban on returning the way leading through Egypt reflects the conviction that a return journey by the same way signifies going back to the past, which invalidates the event of liberation from Egyptian slavery and the future opened by it.

21 Cf. D.M. Sharon, "When Fathers Refuse to Eat: The Trope of Rejecting Food and Drink in Biblical Narrative”, pp. 135-148, especially p. 137nn. 
ing with a prophet from Bethel, for he believes that the word of the LORD has only instructed him to object to the king's actions. This moment of surprise is used by an old prophet who feels at home there, and his old age reflects life experience and wisdom, giving him an advantage over the man from Judah, probably much younger, and further alienated by his mission. ${ }^{22}$ No wonder that the former becomes the main character of the next scenes, which take place according to his words and behavior.

At the beginning, his absence from state-religious ceremonies seems to be puzzling. Does it imply distancing and lack of acceptance for the changes introduced by the king? Why, then, does he let his sons participate in them? ${ }^{23}$ An accurate report on their course, which one of them first communicates to him, and then both of them attest, confirms his keen interest in what happened during the feast (v. 11). He does not want to take part in it, but he wants to know its course. He is particularly moved by the report of the man of God who showed great courage and, above all, obedience to the word of God. He himself lacks both qualities. Why, then, does he ask his sons where the man of God went? Does he want to confront a young man who turned out to be more faithful to God than him (v. 12)? And why does he ask to saddle a donkey for himself so that he can meet him personally and check the constancy of his decisions (v. 13)? Religious rivalry over who has greater authority begins at this point.

After finding a young prophet sitting under the oak, he asks him to make sure if he is the man of God who came from Judah (v. 14). The question stems not only from the obvious fact that he sees him for the first time, but also concerns his identity: whether he is there as the man sent by God, or whether he is someone else who has decided that his mission is completed.

The man from Judah with a short answer "I am" confirms his identity, although it will soon turn out that he does not realize the ambiguity of his answer. And then the old prophet invites him to a meal at his home. From that moment, food becomes the main topic of their conversation, first there, under the tree, and later in Bethel (in vv. 15-24 it appears 8 times), and for the man of God the main dilemma is whether to let hunger speak or to obey the word of God. As it might be expected, the man of God refuses first (vv. 16-17), but the

22 In 2 Kings 9:1-4, Elisha sends a young prophet with a similar mission to the future king Jehu.

23 It is different from the view of J.C. Long, Jr (1 \& 2 Kings, p. 171) as for him the answers to these questions are not crucial. However, in the structure of the plot, especially the personal profile of the old prophet, they have a decisive meaning, because the second, longer part of this episode presents him as someone who deals cards and completely subordinates to himself a young prophet. It is true that the man from Judah fulfilled the task entrusted to him, but his fate is now in the hands of the old prophet. 
old prophet manages to persuade him to accept the invitation (v. 18). How has he achieved it? The narrator explains that he has cheated on him. Where lies the deceit then? The decisive thing is to invoke a direct revelation from God: "an angel spoke to me by the word of the LORD." This is the linguistic trap of an old prophet. Whenever God speaks through his envoy, usually there is a full formula: an angel of the $L O R D / G o d$ (see Genesis 16:7-11, 22:11.15, 31:11, Ex 3:2, Judg. 6:11 etc.). This last, key word, confirming the authenticity of God's message is missing and the young man does not catch it. He trusts the formula "by the word of the LORD", which the old prophet cleverly picks up from his refusal. Thus the rhetorical manipulations of the prophet of Bethel rely on the skillful use of the formula of God's revelation "by the word of the LORD". The man from Judah could not recognize his earlier words when the old prophet said to him, "I too am a prophet as you are," the young man should ask himself: "if he confessed to me that he was a prophet, why didn't he appear to be a prophet to his king and why did he remain silent when Jeroboam established new shrines with the cult and the liturgical calendar contrary to the Law of Moses? Why did God not reveal Himself to him in order to reprimand the king, but only to turn me back from my way?"

Why is the man of God susceptible to the manipulation of the old prophet who has not received any God's revelation for a long time and who, as it can be seen from the conversation, shows great skill in using religious language to emphasize his own authority? The answer lies in the suggested perspective of the meal at his home in Bethel. Obviously, this is more than just a feast, the stake in the game is a way of living in prosperity. In the light of it, the real relationship of the man from Judah to the word of the LORD is also revealed. Accepting the invitation of the old prophet, he shows that he does not fully understand the essence of his mission. He treats it as a task resulting from his prophetic profession, after which he feels released from his obligations. He separates himself from his message. He decides that it applies only to the king and his religious policy, and that he himself is not included in its content. Instead of accepting the word of the LORD as food, and live and be faithful to it until the end (see Jer 15:16), he returns to Bethel to eat bread and drink water there. He replaces the hunger for God's word with an appetite for good food. In the place of hunger of the word of God the temptation to satisfy the hunger for bread appears (see Mt 4:2-4). Therefore, the invitation of the old prophet has fallen on fertile ground.

Retrospectively, it is possible to re-evaluate his refusal to participate in the royal feast. It is not so much about the words he said to the king, quoting God's exact command, or how he spoke them, but, above all, about how he understood them. He accepted the words of God as an external order, to be obeyed 
externally, without internal, subjective assimilation, inducing thoughts to think about what it means to him personally and to what extent it concerns his identity. The question is, what kind of reader of God's word the man from Judah is. He repeats the exact word of God and obeys it externally. Is it sufficient to be a prophet? Has he done it with his own conviction resulting from a full understanding of God's message concerning his person? It seems that he did not interpret the word of God in such a manner. Thus, the attitude in the confrontation between religion and politics depends, to a large extent, on the interpretation of the word of the Lord. The man of God was convinced of the legitimacy of his opposition to the changes introduced by the king in the religious sphere, but he did not see the need to object to its instrumental use for political purposes. Indeed, he refused to accept the invitation, but it did not result from his deep conviction, rather from external circumstances. The overlap of the time of the prophecy and invitation made him unable to accept it without diminishing the power of the message, on which the king counted. He was also tempted to accept the change in the hostile attitude of the king and assess his attitude according to publicly expressed kindness towards him and not to the word which once spoken would have had a weaker impact due to his indecision.

Without being internally faithful to the word of the LORD, the man from Judah could not resist the invitation of the prophet from Bethel to return with him and eat a meal at his home. He could also interpret his gesture as a manifestation of solidarity of the old prophet. During the feast together, the old prophet heard the word of the LORD, which made him turn to the man of God: "Thus says the LORD: Because you have disobeyed the word of the LORD and have not kept the commandment which the LORD your God commanded you but you came back, ate bread and drank water in the place of which the LORD said to you: 'Eat no bread or drink no water', your corpse shall not come to the tomb of your fathers." (vv. 20-22). Why did he not understand his mistake earlier? Because only now, during the feast, did he realize that he gained nothing. He did not strengthen his authority, and his guest, eating to his heart's content, became like him, a prophet who had brought him back from his path, appointed to him by God. This is the turning point of the whole story. The old prophet will be called the prophet who had brought him back three times (1 Kings 13:20.23.26) as if it was his real identity, revealed for him during a meeting with the man of God from Judah. It is a narrative anagnorisis - recognition. He saw himself as someone who betrayed the word of the LORD and did not fulfill his prophetic calling, keeping silent of the king's actions. The young man from Judah, however, does not participate in this recognition, because he does not understand the whole situation at all and this is his drama, because when he has finished eating and drinking, he wiped his mouth and saddled the 
donkey the old prophet gave him ( v. 23). He became someone like the prophet from Bethel, the one who turned his back on God, with hunger for bread and with eyes fixed on material goods. Returning on the donkey of the old prophet, he became completely like him, as he chose silence for satiety and privileges ensuring a comfortable and prosperous life.

\section{The Old Prophet, the Donkey and the Lion (13:24-32): to Eat or Not to Eat?}

The man of God decided to eat. He started his return journey to Judah full and with a donkey which was a gift from the old prophet from Bethel. And what did the lion which met him and killed him do (v.26)? He did not eat his body or the donkey standing next to him. ${ }^{24}$

The return of the man of God from Bethel does not end his story. But in the last part of it he does not appear as the main character, although by virtue of God's mission he was at the beginning. Only his dead body abandoned by the road features in the story (v. 24). In the whole episode, it is mentioned as many as ten times, exactly the same number as the bread and water before. The man of God refused to eat bread twice but only partially because finally he sat down and ate to his full. And now his body is food for the lion, but the animal refuses to eat it, which is against its nature. Thus the story shows the gradual degradation of the man from Judah. From the man of God, courageously proclaiming the word of the LORD, through someone for whom the hunger of bread turned out to be stronger than the hunger of the word, to the silent but satiated cadaver abandoned on the road. Appetite for good food allowed him to strengthen the body, but what was the effect of it, if the body emptied of the word of the Lord became completely useless? In this context, the behavior of the lion is unusual. Sent with the mission of killing the man from Judah, according to the word of God, the lion did the job, refraining, however, from eating the body of the man, moreover, he did not tear apart the donkey. The wild animal was able to resist its instincts and endure hunger. The man of God could have survived without food if he had accepted the word of the Lord as food. Satiated, he is a useful and thoughtless tool for the political power, but for God he remains a dead body, useless in his infirmity. Can the reputation of a prophecy still be saved by the old prophet?

When he heard about what had happened on the road to Bethel, he knew at once that it was the man of God who disobeyed the word of the LORD. He

24 A donkey is mentioned seven times here, whereas a lion five times. 
came to the abandoned body and found a donkey and a lion nearby. What has he learnt from this event that happened to both of them in confrontation with political power? The young man from Judah sent to the king as a true prophet eventually becomes a false prophet who, by putting the hunger for bread over the hunger of the word, betrays his mission. He himself, as an old and false prophet, exposing the lost man of God, re-established the word of the LORD in its power and inevitability. So did the prophet of Bethel convert and become a true prophet? ${ }^{25}$

At first, he is a corrupt prophet, unable to oppose the king. Being in possession of at least two donkeys, he is a wealthy man. A cursory reading does not focus on the issue of his wealth and social position. And this is the reason why he chose to remain silent because he had too much to lose. Similarly, the problem of eating is overlooked in assessing the motives of the man of God from Judah. His story is not just about whether he has to eat or not. The question of who offers a meal and whether in return he demands loyalty is equally important. A refusal to eat bread could mean that his only food must be the word of God and his only loyalty - faithfulness to God. Refusing food to satisfy the hunger of bread, the prophet becomes a witness to the hunger of the word, as Amos reminds: " 'Behold, the days are coming, says the Lord, 'that I will send a famine on the land, not a famine of bread nor a thirst for water, but hunger of hearing the words of the LORD' ". (Am 8:11).

Are there any criteria to distinguish between true and false prophets? The dispute of Micah with the prophets serving political power in 1 Kings 22 suggests that the latter also enjoy some kind of divine inspiration, although this is a lying spirit, to which God himself consented (see 1 Kings 22:19-23). He allows the prophets of the state to work in order to show the radical and uncompromising nature of a true prophecy. The action of the "lying spirit" is mainly to ensure the king in doing something he has already decided to do but which is contrary to both common sense and the will of God. ${ }^{26} \mathrm{~A}$ deceitful king has always at hand those who spread lies confirming him in his blindness and stubborn implementation of the chosen strategy, usually leading to a catastrophe. The old prophet behaves in a similar way, he also preaches falseness, invoking God's inspiration, but finally he exposes the disobedience of the man of God and his own subordination to royal power in return for material benefits and privileges. The true prophet is, at the same time, faithful to the word of God and

25 Cf. J.C. Long, Jr, 1 \& 2 Kings, p. 173: Asking his sons to bury him in the tomb of the man from Judah, the old prophet confirms the truthfulness and credibility of the word of the LORD.

26 Cf. S.K. Tonstad, God of Sense and Traditions of Non-Sense, p. 223n. 
faithful to himself in his otherness in relation to the expectations and claims of political power. He is also aware of the price he must pay for this faithfulness: he will remain hungry and a stranger.

\section{The Ending: Historizing Parable or Hermeneutics of History?}

Biblical stories are not a monologue, one voice does not reverberate or one topic is not dominant. Rather, there are many voices which create polyphonic narratives. According to M. Bachtin, emphasizing human affairs, their course in time and location in space from various, often incompatible or opposite viewpoints, they become closer to life, which is as such a polyphonic element with a varied thematic orientation. From this perspective, 1 Kings 13 is not a monothematic parable of the prophets or a political allegory. As a polyphonic tale, it presents hermeneutics of history, which shows the mechanisms which construct it, not only are human beings the main heroes in individual episodes but also various factors and conditions which influence the structure of the story and its direction. Politics and religion are not abstract systems, but are expressed in the attitudes of people whose lives are inextricably interwoven by personal relationships in one common but multi-layered history.

The king, as the representative of political power, tries to subordinate all areas of social life to himself, including religion which is an effective tool to influence people in order to maintain his rule as long as possible. He is not interested in dividing politics and religion. The man of God, in turn, guided by the independence of religion as a sphere subjected exclusively to the word of God, does not fulfill his mission, becoming a partner of the old prophet in his silent agreement to the king's action. The prophet from Bethel is the most interesting figure coming to the fore as the events unfold. Due to his absence during the ceremonies, he distances himself from the claims of political power to manage religion but, at the same time, he is afraid to openly express his opposition to the king. This silence is significant because he is aware of how much he can lose, especially the privileges and material benefits already achieved. His position, and perhaps jealousy for greater prestige and prophetic authority, even in the eyes of his sons, must have cast doubt about the uncompromising nature of the man from Judah in the dispute with the king. The course of their mutual relations reveals the motives which guide them. The problem of the authority of the prophet and his credibility appears here. Undoubtedly, the old prophet from Bethel realized that he had lost all prestige of being a prophet in favor of the young man from Judah. Subjecting him to a specific test, the old prophet wishes to regain his own authority, which is easier because it does not cost him 
much, perhaps the loss of the donkey that he gave to the young man from Judah who thus becomes a corrupt prophet like him.

The first episode presents a confrontation of religion and politics, in which the task of the man from Judah is to unmask the real intentions behind the vision of the new state and its religion in the kingdom of Jeroboam. In the second episode, there is a dispute within religion about the attitude to politics. The old prophet represents poorly disguised dependence of religion on politics in his silent distance from the actions of the king. The man of God from Judah prophesizes against a subjection of religion to political power, but he succumbs to the old prophet of Bethel, discredited by silence thus obscuring the truth of his message, condemning politics to manipulation which serves to maintain power and religion to the impotence of ritualistic celebrations.

It is the Bethel prophet who becomes the protagonist of the second episode and we can learn much from him. The man of God remains passive, unable to oppose him as the partner of Jeroboam and thus he also shares the blame for his sins. Renouncing faithfulness to the word of God, which he does not make his inner conviction, he must rely on the authority of the old prophet, deprived of the word of the LORD. But fortunately, the latter understood his mistake, and his change is expressed by the fact that the word of God proclaimed by the man of God from Judah, despite his weakness, will be fulfilled and the mission entrusted to him will be completed. Thus the preachers of the word never live up to the content of the message proclaimed in the name of God. This does not, however, undermine the very word, the strength of which is God's faithfulness accompanying the sinful people.

The position of the narrator in his way of portraying characters is also worth attention. He does not allow the prophets to enter into a discussion with the political authority to convince it of a change. Their task is to admonish because the epilogue of the whole event in 1 Kings 13:33-34 shows that the king, despite the recognized sign from God (the disintegration of the altar and healing of his hand) does not change his policy and continues the chosen plan, leading the people until the final destruction of the nation

It is not far from the truth to say that to some extent we are what we eat and how we eat. ${ }^{27}$ Consumption of meals plays an important role in shaping our identity. In a sense, food becomes a political and religious act, especially when it takes place during important social events or celebrations. Both spheres, however, differ significantly in their relationship to food. In politics,

27 Man is what he eats. Today this saying is very popular. Those who repeat it think rather about a proper diet. Apart from bread the Bible uses the word as a term for food and frequently juxtaposes these two terms signifying two ways or styles of life. 
it is important who you sit with during your meal and whose guest you are. In religion, what you eat (clean/unclean) and who prepares your food (your own/ stranger) is more significant. The final issue is the symbolic sphere, when someone refuses to take part in a meal not only due to his personal taste preferences but also refers to it with a feeling of disgust. ${ }^{28}$ In relation to politics, this person questions the system of power, and in relation to religion undermines the universally accepted image of God. If someone feeds only on bread, bread also becomes the only driving force of his life. The prophet is a man of word and nourishes himself with the word (Eze 2:8-3:3). The word of the LORD is not only the source of his vocation and mission, but also determines the limits of his whole existence. In other words, as a man he must eat to live but under the conditions dictated to him by the word of God. The behavior of the man of God expresses his attitude to God's word with regard to food. He repeats it like a slave as if he wanted to make it his shield, with the help of which he would be able to defend himself against being invited to participate in the king's feast. The word of God becomes for him an ideological weapon which is sufficient to distinguish himself from political power by refusing an invitation to a meal, but it is not enough for the religious rhetoric used by the old Bethel prophet. The latter is a great exegete of the word of God: with his historical interpretation he sets a trap for the young man. However, the man of God would keep his opinion if he internalized the word of God. What remained was the hunger for bread in the literal physical sense. The key is therefore the ability to distinguish a false religion from the real one, and the stake in this game is the attitude to food and words: the mouth is used to eat food and speak words, but the food is used in Eze 2-3 as a metaphor for listening to the word written in a scroll. ${ }^{29}$ Eating in its material dimension sustains biological life, but the word of God creates identity, defines who the person is, setting a mental framework in which the desire to live a life faithful to God is more valuable than the appetite for good food and material well-being. False religion subordinates the word of God to broadly understood consumption, which certainly an exaggerated, but also horrifying, depiction is presented the scene from 1 Sm. 2:12-17. Hophni and Phinehas, the sons of Eli and also the priests of the LORD who serve in the sanctuary of Shiloh are called the "sons of Belial" (useless/corrupt) and are presented as having unrestrained appetite. When hungry, they cannot wait for the end of the sacrifice rite, but demand that the servants bring them meat still

28 C.A. Hastorf, The Social Archeology of Food, p. 11. Cf. Eze 4:12-15; Acts 10:10-14.

29 The distinction between true and false religions is used by J. Assmann in his latest publications. He describes it as the Mosaic distinction, see The Price of Monotheism, pp. 8-30. 
boiling in the cauldron; moreover, the cooked meat does not satisfy them, they already take raw meat before fat is burned for the sacrifice to God as the roasted meat tastes better. For them, religion serves exclusively consumption.

Thus the multiplicity of plots and polyphony of the story in 1 Kings 13 is a considerable challenge for modern readers. It is not a simple account, instead it contains a hermeneutic key to learn the story, especially this part of it which remains invisible to the characters. Interpreting their complex and intricate lives, the reader is able to learn how to investigate the hidden intentions and motives of human behavior and their religious, social and political repercussions.

\section{Bibliography}

Assmann J., Pamięć kulturowa. Pismo, zapamiętywanie i polityczna tożsamość w cywilizacjach starożytnych, Warszawa 2008.

Assmann J., The Price of Monotheism, Stanford 2010.

Boer R., "National Allegory in the Hebrew Bible," Journal for the Study of the Old Testament 74 (1997), pp. 95-116.

Dietler M., "Feasts and Commensal Politics in the Political Economy. Food, Power and Status in Prehistoric Europe," in: Food and the Status Quest: An Interdisciplinary Perspective, eds. P. Wiessner, W. Schiefenhövel, Oxford 1996, pp. 87-125.

Hastorf C.A., The Social Archeology of Food. Thinking about Eating from Prehistory to the Present, New York 2017.

Leithart P.J., 1 \& 2 Kings, London 2006.

Long J.C., Jr., 1 \& 2 Kings, The College Press NIV Commentary, Joplin, Missouri 2002. MacDonald N., Not Bread Alone: The Uses of Food in the Old Testament, Oxford 2008.

Sharon D.M., "When Fathers Refuse to Eat: The Trope of Rejecting Food and Drink in Biblical Narrative," Semeia 86/1 (1999), pp. 135-148

Smith J.M., "Apostrophe or the Lyric Art of Turning Away," Texas Studies in Literature and Language Vol. 49, No. 4 Winter 2007, pp. 411-437.

Tonstad S.K., God of Sense and Traditions of Non-Sense, Eugene, Oregon 2016.

Van Winkle D.W., "1 Kings XIII: True and False Prophecy," Vetus Testamentum XXIX, 1 (1989), pp. 31-43.

Walsh J.T., 1 Kings, Collegeville, Minnesota 1996. 